\title{
NOTE
}

\section{Microsatellite variation and rare alleles in a bottlenecked Hawaiian Islands endemic: implications for reintroductions}

\author{
Michelle H. Reynolds ${ }^{1, *}$, John M. Pearce ${ }^{2}$, Philip Lavretsky ${ }^{3}$, Pedro P. Seixas ${ }^{4}$, \\ Karen N. Courtot ${ }^{1}$ \\ ${ }^{1}$ US Geological Survey, Pacific Island Ecosystems Research Center, PO Box 44, Hawai'i National Park, Hawai'i 96718, USA \\ ${ }^{2}$ US Geological Survey, Alaska Science Center, 4210 University Drive, Anchorage, Alaska 99508, USA \\ ${ }^{3}$ Wright State University, 3640 Colonel Glenn Hwy, Dayton, Ohio 45435, USA \\ ${ }^{4}$ Centro de Reprodução Anatideos, Rua Mário Pais da Costa, no. 53, 3515-174 Viseu, Portugal
}

\begin{abstract}
Conservation of genetic biodiversity in endangered wildlife populations is an important challenge to address since the loss of alleles and genetic drift may influence future adaptability. Reintroduction aims to re-establish species to restored or protected ecosystems; however, moving a subset of individuals may result in loss of gene variants during the managementinduced bottleneck (i.e. translocation). The endangered Laysan teal Anas laysanensis was once widespread across the Hawaiian archipelago, but became isolated on Laysan Island (415 ha) from the mid-1800s until 2004 when a translocation to Midway Atoll (596 ha) was undertaken to reduce extinction risks. We compared genetic diversity and quantified variation at microsatellite loci sampled from 230 individuals from the wild populations at Laysan (1999 to 2009) and Midway (2007 to $2010 ; \mathrm{n}=133$ Laysan, $\mathrm{n}=96$ Midway birds). We identified polymorphic markers by screening nuclear microsatellites $(\mathrm{N}=83)$. Low nuclear variation was detected, consistent with the species' insular isolation and historical bottleneck. Six of 83 microsatellites were polymorphic. We found limited but similar estimates of allelic richness (2.58 alleles per locus) and heterozygosity within populations. However, 2 rare alleles found in the Laysan source population were not present in Midway's reintroduced population, and a unique allele was discovered in an individual on Midway. Differentiation between island populations was low $\left(F_{\mathrm{ST}}=0.6 \%\right)$, but statistically significant. Our results indicate that genetic drift had little effect on offspring generations 3 to 6 yr postrelease and demonstrate the utility of using known founder events to help quantify genetic capture during translocations and to inform management decisions.
\end{abstract}

KEY WORDS: Anas laysanensis - Island endemic - Genetic diversity - Laysan duck · Reintroduction biology

\section{INTRODUCTION}

A fundamental aspect of management for species conservation should be preservation of genetic variation so that natural selection and other processes have the potential to respond to environmental

\footnotetext{
*Corresponding author: mreynolds@usgs.gov
}

change (Reed \& Frankham 2003, Frankham 2005). The application of molecular techniques to examine levels of genetic variation may provide valuable information to aid in the genetic management of endangered populations for long-term resilience (e.g. adaptation capacity in the face of new diseases

() The authors 2015. Open Access under Creative Commons by Attribution Licence. Use, distribution and reproduction are unrestricted. Authors and original publication must be credited. 
or other biotic and abiotic environmental changes). If endangered species recovery strategies include reintroduction, translocations with small numbers of founders and no immigration can lead to loss of genetic variation over time via genetic drift or low initial genetic capture (Weeks et al. 2011) and can potentially reduce the reintroduced population's long-term persistence or its potential to serve as a suitable source for future translocations (Tarr et al. 1998, Groombridge et al. 2012, Weiser et al. 2013).

The endangered Laysan teal (or Laysan duck, Anas laysanensis) was isolated on a small remote atoll (412 ha) in the Northwestern Hawaiian Islands, Laysan Island, for $>150$ yr (Olson \& Ziegler 1995). Ancient DNA testing, historical accounts, and sub-fossil remains indicate the Laysan teal occurred throughout the Hawaiian archipelago approximately $800 \mathrm{yr}$ ago, but, like other Hawaiian birds, it was extirpated from islands following the arrival of humans and introduced mammals (Olson \& James 1991, Cooper et al. 1996). The Laysan teal declined to near extinction ( 7 to 20 individuals) following the intentional introduction of European rabbits (Oryctolagus cuniculus) to Laysan Island around 1905 (Dill \& Bryan 1912). The last remaining Laysan teal population grew to the island's carrying capacity of about 400 to 600 (Seavy et al. 2009) in the decades after rabbits were eliminated from Laysan Island in 1924. Two recent population declines were documented, first in 1993 to 1994, when abundance fell to about 150 adults during a severe drought and epizootic (Seavy et al. 2009), and then an estimated decline of about $42 \%$ in 2011 to 2012 after the Tōhoku earthquake-generated tsunami (Reynolds et al. 2015). Since Laysan teal do not migrate or immigrate between distant Northwestern Hawaiian atolls, the establishment of 4 additional populations is a recovery criterion to reduce the inherently high extinction risk associated with a single small population (USFWS 2004, 2009). An experimental translocation (wild to wild) was implemented in 2004 and 2005, moving 20 and 22 juvenile birds, respectively $(<4 \%$ of the total post-fledgling population at Laysan Island; Reynolds et al. 2008, 2015). The translocated population grew rapidly to $471-535$ post-fledglings by 2008 (Reynolds et al. 2012, 2013).

Since recovery strategies for Laysan teal emphasize translocations (USFWS 2009), periodic genetic assessments of populations are valuable to understand how genetic variation changes over time (i.e. genetic drift) between source and translocated populations. This information is useful in informing management decisions such as the optimal number of founders and immigrants to translocate. These decisions are likely to influence both short- and longterm retention of genetic diversity within reintroduced populations. In this study, we examined microsatellite variation in Laysan teal from the source island population of Laysan and from the reintroduced population of Midway Atoll. We compared microsatellite genetic diversity of the 2 populations and tested for evidence of allelic loss in the offspring generations produced at Midway Atoll 2 to 6 yr posttranslocation.

\section{MATERIALS AND METHODS}

On Laysan Island $\left(25^{\circ} 46^{\prime} \mathrm{N}, 171^{\circ} 44^{\prime} \mathrm{W}\right)$ from 1999 to 2009, we caught Laysan teal and collected blood ( $\mathrm{n}=$ 84) or feathers, including rectrices or body feathers $(\mathrm{n}=27)$. Additionally, we recovered carcasses and froze tissue samples $(\mathrm{n}=22)$. The 133 ducks sampled from Laysan Island (62 females, 59 males, and 12 juveniles of unknown sex) included 22 of the 42 original founders of Midway Atoll $\left(28^{\circ} 11^{\prime}-28^{\circ} 16^{\prime}\right.$ N, $177^{\circ} 18^{\prime}-$ $\left.177^{\circ} 25^{\prime} \mathrm{W}\right)$. We also trapped birds at Midway Atoll and collected feathers from 5 individuals and tissue samples from 91 fresh carcasses representing the $F_{1}$ to $\mathrm{F}_{6}$ generations, from 2007 to 2010 (39 females, 48 males, and 9 juveniles of unknown sex). Samples were preserved in lysis buffer $(0.1 \mathrm{M}$ Tris, $\mathrm{pH}$ 8.0, $0.1 \mathrm{M}$ EDTA, 2\% SDS [sodium dodecyl sulfate]) and frozen. The source population size varied from about 435 to 674 birds from 1999 to 2009 (Reynolds et al. 2015), and the translocated population varied from about 250 to 475 between 2007 and 2010 (Reynolds et al. 2012), so our population sampling approached approximately 20 to $31 \%$ of the population at Laysan and 20 to $38 \%$ of the population at Midway.

We used a subset of samples to screen for variation in microsatellite genetic markers with the intent of examining the larger dataset once variable markers were identified. For microsatellite loci, we screened 18 to 31 samples from Laysan Island for a total of 83 microsatellite primer pairs and examined results for allelic variation. The majority of these primers came from published sources examining the variation of microsatellites in waterfowl (Fields \& Scribner 1997, Buchholz et al. 1998, Cathey et al. 1998, Maak et al. 2003, Paulus \& Tiedemann 2003, Denk et al. 2004, Munoz-Fuentes et al. 2005) and other species (Primmer et al. 1995). PCR amplification of all nuclear loci during screening and data collection involved identical reagent cocktails as described in Pearce et al. (2004), except that all were amplified with the same 
PCR temperature profile $\left(94^{\circ} \mathrm{C}\right.$ for 2 min followed by 40 cycles of $94^{\circ} \mathrm{C}$ for $2 \mathrm{~min}, 50^{\circ} \mathrm{C}$ for $1 \mathrm{~min}$, and $72^{\circ} \mathrm{C}$ for $1 \mathrm{~min}$ ) by means of an MJ Research PTC-200 thermal cycler. PCR products were visualized on $6 \%$ polyacrylamide gels with a LI-COR 4200 DNA sequencer. Genotypes were scored according to allele size on the basis of an initial comparison to an M13 DNA sequence ladder and then to samples established as size standards that were run on each subsequent gel.

Of the 83 microsatellite loci screened, a total of 68 primer pairs yielded a PCR product and, of those, 9 loci $(13.2 \%)$ were variable among the test samples. However, 3 of these 9 loci were difficult to reliably score and were subsequently dropped. Thus, we analyzed all 229 samples comprising 133 individuals from Laysan Island and 96 from Midway Atoll with the 6 loci that were polymorphic and reliably scored: Bca3 (Buchholz et al. 1998), Smo4, Smo6, Smo11 (Paulus \& Tiedemann 2003), Aph21 (Maak et al. 2003), and Sifu 8 (Fields \& Scribner 1997; Table 1). Approximately $25 \%$ of genotypes (range per locus: 10 to $50 \% ; 342$ samples) were amplified more than once across the 6 microsatellite loci to verify genotypes, and all genotypes were scored twice by independent observers. From these data, 6 discrepancies were observed, yielding an overall error rate of $1.8 \%$. We used MICROCHECKER (Van Oosterhout et al. 2004) to test for evidence of null alleles in our microsatellite data set. We calculated allelic richness (i.e. the number of alleles per locus), expected $\left(H_{\mathrm{e}}\right)$ and observed heterozygosities $\left(H_{\mathrm{o}}\right)$, and inbreeding coefficient $\left(F_{\mathrm{IS}}\right)$ for microsatellite loci in FSTAT v. 2.9.3 (Goudet 1995). HardyWeinberg equilibrium and linkage equilibrium (LE) were tested in GENEPOP v. 3.1 (Raymond \& Rousset 1995; Markov chain parameters: dememorization number 1000; number of batches: 100; and number of iterations per batch: 10000$)$.

A relative estimate of differentiation $\left(F_{\mathrm{ST}}\right)$ between Laysan Island and Midway Atoll samples was estimated in ARLEQUIN v. 3.5 (Excoffier \& Lischer 2010). Population structure was further analyzed in the program STRUCTURE v. 2.1 (Pritchard et al. 2000), which uses Bayesian clustering methods to determine the number of genetic populations. Datasets were analyzed for $(K)$ populations ranging from 1 to 5 . Data were analyzed using an admixture model assuming correlated frequencies, without a priori knowledge of island source. Burn-in periods of 10000 steps followed by 100000 Markov chain Monte Carlo iterations were used. Analyses at each $K$ were repeated 5 times to evaluate consistency across runs. The log likelihood was used to determine the optimum $K$.

\section{RESULTS}

Observed heterozygosity conformed to expected Hardy-Weinberg proportions for the 6 microsatellite loci, and there was no evidence of linkage disequilibrium for the data set $(\mathrm{n}=229)$. For the 6 microsatellite loci, the number of alleles per locus and allelic richness were nearly the same for the 2 island groups (Table 1), with an average of 2.58 alleles per locus (range: 2 to 4 alleles per locus; Table 2). However, 2 alleles were unique to the source population (Smo4, Allele 291: 2 individuals; Sfiu8, Allele 144: 4 individuals), while a third allele (Aph21 locus, Allele 176)

Table 1. Metrics of genetic diversity across 6 nuclear microsatellite loci for 2 populations (source and translocated) of the Laysan teal Anas laysanensis in the Hawaiian archipelago

\begin{tabular}{|lcc|}
\hline Genetic diversity metric & $\begin{array}{c}\text { Laysan Island } \\
\text { (source) } \\
\mathrm{n}=133\end{array}$ & $\begin{array}{c}\text { Midway Atoll } \\
\text { (translocated) } \\
\mathrm{n}=96\end{array}$ \\
\hline No. of alleles & 2.67 & 2.50 \\
Allelic richness & 2.64 & 2.45 \\
Observed heterozygosity $\left(H_{\mathrm{o}}\right)$ & 0.476 & 0.442 \\
Expected heterozygosity $\left(H_{\mathrm{e}}\right)$ & 0.476 & 0.442 \\
Inbreeding coefficient $\left(F_{\mathrm{IS}}\right)$ & -0.009 & 0.020 \\
Fixation index $\left(F_{\mathrm{ST}}\right)$ between & $0.006(\mathrm{p}=0.03)$ \\
populations & & \\
\hline
\end{tabular}

Table 2. Microsatellite allele frequencies for 2 populations of the Laysan teal Anas laysanensis in the Hawaiian archipelago. Private alleles present in only 1 population are shown in bold

\begin{tabular}{|lccc|}
\hline Locus & Allele & $\begin{array}{c}\text { Laysan Island } \\
\text { (source) } \\
\mathrm{n}=133\end{array}$ & $\begin{array}{c}\text { Midway Atoll } \\
\text { (translocated) } \\
\mathrm{n}=96\end{array}$ \\
\hline Bca3 & 169 & 0.238 & 0.244 \\
& 173 & 0.761 & 0.755 \\
Smo4 & 279 & 0.028 & 0.010 \\
& 283 & 0.580 & 0.636 \\
& 287 & 0.383 & 0.352 \\
Smo6 & $\mathbf{2 9 1}$ & $\mathbf{0 . 0 8 1}$ & $\mathbf{0 . 0 0 0}$ \\
& 146 & 0.435 & 0.542 \\
Smo11 & 151 & 0.564 & 0.457 \\
Aph21 & 199 & 0.608 & 0.688 \\
& 205 & 0.392 & 0.311 \\
& 169 & 0.647 & 0.724 \\
Sfiu8 & $\mathbf{1 7 6}$ & $\mathbf{0 . 0 0 0}$ & $\mathbf{0 . 0 5 2}$ \\
& 177 & 0.325 & 0.255 \\
& 181 & 0.027 & 0.015 \\
& $\mathbf{1 4 4}$ & $\mathbf{0 . 0 1 8}$ & $\mathbf{0 . 0 0 0}$ \\
& 146 & 0.476 & 0.533 \\
& 152 & 0.504 & 0.466 \\
\hline
\end{tabular}


was found only in the Midway group from an unbanded juvenile bird in 2008 (offspring generations $\mathrm{F}_{1}$ to $\mathrm{F}_{4}$ ) that died of avian botulism type C (Clostridium botulinum) (Table 2). The presence of this unique allele on Midway could be due to a mutation post-translocation or a rare allele that has not yet been sampled in the source population. Analysis run in MICRO-CHECKER found no evidence for null alleles across all loci and both populations.

Observed heterozygosity ranged from 32 to $57 \%$ across loci and for both island groups (Table 1). Although the inbreeding coefficients (comparing the heterozygosity within sampled individuals from the population) were not significantly different from zero $(p>0.05)$, they were higher on Midway Atoll (0.020) compared to Laysan Island $(-0.009)$. Overall $F_{\mathrm{ST}}$ between the 2 populations was low but statistically significant $\left(F_{\mathrm{ST}}=0.006, \mathrm{p}=0.03\right)$. STRUCTURE identified an optimum $K$ of 1 , suggesting populations on the 2 atolls were undifferentiated genetically.

\section{DISCUSSION}

The low genetic variation at these loci for Laysan teal is consistent with historical accounts of a population bottleneck and a genome-wide loss of variation. The Laysan teal harbors low genetic diversity compared to other island endemics (e.g. Tarr et al. 1998, Fowler et al. 2009, Bowker-Wright et al. 2012), likely due to its comparatively long isolation and radical range restriction from across the Hawaiian Archipelago to a 412 ha remote island. Long-term genetic management of reintroduced species is often a low priority when short-term population establishment is successful. Fortunately, the 42 birds trapped and translocated from Laysan Island to Midway Atoll were selected from different family groups during 2004 and 2005, and our results confirm genetic capture of some rare alleles detected in the source Laysan population. Importantly, our results indicate very little genetic drift on Midway's offspring (generations $F_{1}$ to $F_{6}$ ) within the early years post-release. Rapid population growth after a population bottleneck has been shown to reduce the magnitude of genetic drift (Murphy et al. 2015), and indeed this rapid population growth was observed at Midway Atoll $(\lambda=1.73$; Reynolds et al. 2008). Allele retention in isolated populations over time is also influenced by the rate of population growth, population abundance, and species' life-history characteristics (Tracy et al. 2011).
In addition to the rare alleles documented in this study, Lavretsky et al. (2014) revealed genetic variation for Laysan teal in exon 2 of the major histocompatibility complex (MHC) I, putatively a functional marker. Although neutral markers (e.g. microsatellites) are not known to be shaped by natural selection (Holderegger et al. 2006), studies have shown a high positive correlation between the functional and neutral marker types in other island birds (Hansson \& Richardson 2005, Wright et al. 2014), suggesting that neutral forces (i.e. genetic drift), rather than selection, may be a predominant force acting on genetic diversity of small island populations. Studies of the Seychelle's warbler indicate that stochastic genetic capture (i.e. number of founding breeders) was the main determinant of allele loss observed in translocated populations and that the loss of rare alleles was primarily due to incomplete genetic capture (Wright et al. 2014). Consequently, maximizing MHC diversity and retaining rare alleles is assumed to be important for the persistence and resilience of species (Frankham 2005, Weeks et al. 2011), as lack of genetic diversity correlates with a species' risk of extinction and disease susceptibility (Frankham 2005).

Given that genetic variation in an isolated species can be lost over time and during translocations, to improve probabilities of retaining the Laysan teal's limited genetic variation, computer simulations of allele retention in small isolated populations (Weiser et al. 2012, 2013) have been used to explore the optimal number of founders and the frequency and number of immigrants needed at translocation sites (Reynolds et al. 2013). New tools, such as next-generation sequencing, may also be useful for future studies to detect elusive genomic variation in Laysan teal and to apply those data to evidence-based conservation and management practices (Allendorf et al. 2010, Angeloni et al. 2012, Wright et al. 2014).

Our results suggest that the Laysan teal, regardless of island, can genetically be considered a single population 6 generations post-release. The presence of unique rare alleles in both populations, however, suggests that a mixture of individuals from Laysan Island and Midway Atoll will help maximize the genetic diversity of future reintroduced populations. In 2014, for example, a nascent reintroduction attempt to Kure Atoll $\left(28^{\circ} 23^{\prime} 33^{\prime \prime} \mathrm{N}, 178^{\circ} 17^{\prime} 36^{\prime \prime} \mathrm{W}\right.$, 100 ha; PMNM 2014, 2015) was sourced from Midway Atoll without founders from Laysan Island. Our study describes the utility of using documented founder events and periodic genetic assessments for informing reintroduction management decisions to aid retention of allelic diversity. 
Acknowledgements. Funding for this research was provided by the US Geological Survey's Wildlife Program, Pacific Island Ecosystems Research Center, and the Alaska Science Center. We thank C. Rehkemper and J. Klavitter (USFWS) for logistical support. J. Rhymer, S. Talbot, and K. Sage provided assistance with screening of microsatellite loci. S. Sonsthagen, T. DeGange, C. Leopold, and J. Peters provided suggestions and reviews of earlier drafts of the manuscript. We thank T. Work and R. Rameyer (USGS-National Wildlife Health Center) for conducting necropsies and C. Rehkemper and J. Klavitter for storing and shipping the samples used in these analyses. All animal handling protocols were approved by the University of Hawai'i Animal Care and Use Committee (Protocol No. 09-677-3), US Fish and Wildlife Service Endangered Species Permit TE 00348328, and Hawai'i State Protected Wildlife Permit WL013-07-1. Microsatellite data are available at: http://dx.doi.org/10. 5066/F72Z13JP. Any use of trade, firm, or product names is for descriptive purposes only and does not imply endorsement by the US Government.

\section{LITERATURE CITED}

Allendorf FW, Hohenlohe PA, Luikart G (2010) Genomics and the future of conservation genetics. Nat Rev Genet 11:697-709

Angeloni F, Wagemaker N, Vergeer P, Ouborg J (2012) Genomic toolboxes for conservation biologists. Evol Appl 5:130-143

Bowker-Wright G, Bell B, Ritchie P, Williams M (2012) Captive breeding and release diminishes genetic diversity in brown teal Anas chlorotis, an endangered New Zealand duck. Wildfowl 62:176-189

Buchholz WG, Pearce JM, Pierson BJ, Scribner KT (1998) Dinucleotide repeat polymorphisms in waterfowl (family Anatidae): characterization of a sex-linked (Z-specific) and 14 autosomal loci. Anim Genet 29:323-325

Cathey JC, DeWoody JA, Smith LM (1998) Microsatellite markers in Canada geese (Branta canadensis). J Hered 89:173-175

Cooper A, Rhymer J, James HF, Olson SL, McIntosh CE, Sorenson MD, Fleischer RC (1996) Ancient DNA and island endemics. Nature 381:484

> Denk AG, Gautschi B, Carter K, Kempenaers B (2004) Seven polymorphic microsatellite loci for paternity assessment in the mallard (Anas platyrhynchos). Mol Ecol Notes 4: 506-508

Dill HR, Bryan WMA (1912) Report of an expedition to Laysan Island in 1911. US Dep Agric Biol Surv Bull 42: $1-30$

Excoffier L, Lischer HEL (2010) Arlequin suite ver 3.5: a new series of programs to perform population genetics analyses under Linux and Windows. Mol Ecol Resour 10: 564-567

> Fields RL, Scribner KT (1997) Isolation and characterization of novel waterfowl microsatellite loci: cross-species comparisons and research applications. Mol Ecol 6:199-202

Fowler AC, Eadie JM, Engilis A Jr (2009) Identification of endangered Hawaiian ducks (Anas wyvilliana), introduced North American mallards (A. platyrhynchos) and their hybrids using multilocus genotypes. Conserv Genet 10:1747-1758

Frankham R (2005) Genetics and extinction. Biol Conserv 126:131-140
Goudet J (1995) FSTAT (Version 1.2): a computer program to calculate F-statistics. J Hered 86:485-486

Groombridge JJ, Raisin C, Bristol R, Richardson DS (2012) Genetic consequences of reintroductions and insights from population history. In: Ewen JG, Armstrong DP, Parker KA, Seddon PJ (eds) Reintroduction biology: integrating science and management. John Wiley \& Sons, Chichester

Hansson B, Richardson DS (2005) Genetic variation in two endangered Acrocephalus species compared to a widespread congener: estimates based on functional and random loci. Anim Conserv 8:83-90

Holderegger R, Kamm U, Gugerli F (2006) Adaptive vs. neutral genetic diversity: implications for landscape genetics. Landscape Ecol 21:797-807

Lavretsky P, Engilis A Jr, Peters J (2014) Major histocompatibility I gene diversity in the critically endangered Laysan duck (Anas laysanensis). Pac Conserv Biol 20: 86-93

> Maak S, Wimmers K, Weigend S, Neumann K (2003) Isolation and characterization of 18 microsatellites in the Peking duck (Anas platyrhynchos) and their application in other waterfowl species. Mol Ecol Notes 3:224-227

Munoz-Fuentes V, Gyllenstrand N, Negro JJ, Green AJ, Vila C (2005) Microsatellite markers for two stifftail ducks: the white-headed duck, Oxyura leucocephala, and the ruddy duck, O. jamaicensis. Mol Ecol Notes 5:263-265

Murphy SM, Cox JJ, Clark JD, Augustine BC and others (2015) Rapid growth and genetic diversity retention in an isolated reintroduced black bear population in the central Appalachians. J Wildl Manage 79:807-818

Olson SL, James HF (1991) Descriptions of thirty-two new species of birds from the Hawaiian Islands. Part I: nonpasseriformes. Ornithol Monogr 45:1-88

Olson SL, Ziegler AC (1995) Remains of land birds from Lisianski Island, with observations on the terrestrial avifauna of the Northwestern Hawaiian Islands. Pac Sci 49: 111-125

Paulus KB, Tiedemann R (2003) Ten polymorphic autosomal microsatellite loci for the Eider duck Somateria mollissima and their cross-species applicability among waterfowl species (Anatidae). Mol Ecol Notes 3:250-252

> Pearce JM, Talbot SL, Pierson BJ, Petersen MR, Scribner KT, Dickson DL, Mosbech A (2004) Lack of spatial genetic structure among nesting and wintering king eiders. Condor 106:229-240

PMNM (Papahānaumokuākea Marine National Monument) (2014) Endangered Laysan ducks successfully translocated in Northwestern Hawaiian Islands. Papahānaumokuākea Marine National Monument Press Release, Honolulu, HI

PMNM (Papahānaumokuākea Marine National Monument) (2015) Translocation of endangered Laysan ducks to Kure Atoll showing tremendous success. Papahānaumokuākea Marine National Monument Press Release, Honolulu, HI

Primmer CR, Moller AP, Ellegren H (1995) Resolving genetic relationships with microsatellite markers: a parentage testing system for the swallow Hirundo rustica. Mol Ecol 4:493-498

> Pritchard JK, Stephens M, Donnelly P (2000) Inference of population structure using multilocus genotype data. Genetics 155:945-959

Raymond M, Rousset F (1995) GENEPOP (Version 1.2): population genetics software for exact tests and ecumeni- 
cism. J Hered 86:248-249

Reed DH, Frankham R (2003) Correlation between fitness and genetic diversity. Conserv Biol 17:230-237

Reynolds MH, Seavy NE, Vekasy MS, Klavitter JL, Laniawe LP (2008) Translocation and early post-release demography of endangered Laysan teal. Anim Conserv 11: 160-168

Reynolds MH, Hatfield JS, Laniawe LP, Vekasy MS and others (2012) Influence of space use on fitness and the reintroduction success of the Laysan teal. Anim Conserv 15:305-317

Reynolds MH, Weiser E, Jamieson I, Hatfield JS (2013) Demographic variation, reintroduction, and persistence of an island duck (Anas laysanensis). J Wildl Manag 77: 1094-1103

Reynolds MH, Courtot KN, Brinck KW, Rehkemper CL, Hatfield JS (2015) Long-term monitoring of endangered Laysan ducks: index validation and population estimates 1998-2012. J Fish Wildl Manage 6:92-101

Seavy NE, Reynolds MH, Link WA, Hatfield JS (2009) Postcatastrophe population dynamics and density dependence of an endemic island duck. J Wildl Manage 73: 414-418

Tarr CL, Conant S, Fleischer RC (1998) Founder events and variation at microsatellite loci in an insular passerine bird, the Laysan finch (Telespiza cantans). Mol Ecol 7: 719-731

Tracy LN, Wallis GP, Efford MG, Jamieson IG (2011) Preserving genetic diversity in threatened species reintro-

Editorial responsibility: Mike Bruford,

Cardiff, UK ductions: How many individuals should be released? Anim Conserv 14:439-446

USFWS (US Fish and Wildlife Service) (2004) Draft revised recovery plan for the Laysan duck (Anas laysanensis). US Fish and Wildlife Service, Portland, OR

USFWS (US Fish and Wildlife Service) (2009) Revised recovery plan for the Laysan duck (Anas laysanensis). US Fish and Wildlife Service, Portland, OR

Van Oosterhout C, Hutchinson WF, Wills DPM, Shipley P (2004) MICRO-CHECKER: software for identifying and correcting genotyping errors in microsatellite data. Mol Ecol Resour 4:535-538

Weeks AR, Sgro CM, Young AG, Frankham R and others (2011) Assessing the benefits and risks of translocations in changing environments: a genetic perspective. Evol Appl 4:709-725

- Weiser EL, Grueber CE, Jamieson IG (2012) AlleleRetain: a program to assess management options for conserving allelic diversity in small, isolated populations. Mol Ecol Resour 12:1161-1167

Weiser EL, Grueber CE, Jamieson IG (2013) Simulating retention of rare alleles in small populations to assess management options for species with different life histories. Conserv Biol 27:335-344

> Wright DJ, Spurgin LG, Collar NJ, Komdeur J, Burke T, Richardson DS (2014) The impact of translocations on neutral and functional genetic diversity within and among populations of the Seychelles warbler. Mol Ecol 23:2165-2177

Submitted: January 5, 2015; Accepted: May 29, 2015

Proofs received from author(s): July 7, 2015 